\title{
Vertical distribution of zooplankton in a shallow peatland pond: the limiting role of dissolved oxygen
}

\author{
Csaba F. Vad ${ }^{1,2 *}$, Zsófia Horváth ${ }^{2,3}$, Keve T. Kiss ${ }^{4}$, Bence Tóth ${ }^{4}$, Attila L. Péntek ${ }^{5}$ and Éva Ács ${ }^{4}$ \\ 1 Doctoral School of Environmental Sciences, Eötvös Loránd University, Pázmány Péter sétány 1/A, H-1117 Budapest, Hungary \\ 2 Department of Systematic Zoology and Ecology, Eötvös Loránd University, Pázmány Péter sétány 1/C, H-1117 Budapest, Hungary \\ 3 Present address: WasserCluster Lunz, Dr. Carl Kupelwieser Promenade 5, AT-3293, Lunz am See, Austria. \\ 4 Danube Research Institute, MTA Centre for Ecological Research, Jávorka Sándor u. 14, H-2131 Göd, Hungary \\ 5 Doctoral School of Biological Sciences, Szent István University, Páter Károly u. 1, H-2103, Gödöllő, Hungary
}

Received 7 April 2013; Accepted 29 July 2013

\begin{abstract}
We investigated the diel vertical distribution patterns of microcrustacean zooplankton (Cladocera, Copepoda) in a shallow pond (max. depth: $70 \mathrm{~cm}$ ) of the Öreg-turján peatland (Ócsa, Central Hungary) during three 24-h periods in July (19-20th), August (17-18th) and September (11-12th) 2011. Environmental variables showed remarkable vertical stratification. Oxygen concentration was close to zero in the entire water column from night until sunrise, while the lower strata (from $20 \mathrm{~cm}$ below the surface) were close to anoxic during all three diel cycles. It proved to be the main determinant of the vertical distribution of microcrustaceans. Accordingly, the highest proportion of individuals was present in the surface layer. Chlorophyll- $a$ concentration and phytoplankton biomass were inversely distributed compared to zooplankton. Microcrustaceans (mainly Daphnia curvirostris) migrated to the middle layer only in August, which could be explained by a trade-off between food resources, dissolved oxygen (DO) and competition with littoral zooplankters. The diurnal density patterns of microcrustaceans suggested horizontal migration into the aquatic macrophytes during night, which could be a strategy to avoid Chaoborus predation. Our results show that strong vertical gradients of abiotic and biotic factors occur even in such shallow waterbodies. Among them, DO can maintain constant vertical aggregation of zooplankters by limiting their occurrence to the surface layers.
\end{abstract}

Key words: chemical stratification / vertical gradients / micro-scale distribution / microcrustaceans / anoxia

\section{Introduction}

The vertical distribution of zooplankton represents a trade-off between multiple selective forces (Winder et al., 2004). In lakes exhibiting thermal or chemical stratification, vertical gradients of abiotic and biotic factors determine optimal depth for zooplankton, where maximal individual fitness and population growth can be achieved. Gradients of temperature, food resources (Lampert et al., 2003; Kessler and Lampert, 2004) or dissolved oxygen (DO) (Sell, 1998; Larsson and Lampert, 2012) highly influence the distribution of zooplankters. These gradients can be rather persistent during stratification and, therefore, lead to relatively constant vertical aggregations of plankton. Diurnally changing effects, such

\footnotetext{
*Corresponding author: vad.csaba@gmail.com
}

as light-dependent predation by fish (Zaret and Suffern, 1976; Gliwicz, 1986) or harmful ultraviolet radiation (UVR) (Rhode et al., 2001; Williamson et al., 2011), however, can drive systematic diel changes in zooplankton vertical distribution (i.e., diel vertical migration).

The vast majority of studies concerning vertical distribution of zooplankton targeted deep (up to tens of metres), stratified lakes and only a limited number of studies investigated shallow systems. In shallow lakes, more focus was put on horizontal patchiness, especially on diel horizontal migration (Lauridsen and Buenk, 1996; Burks et al., 2002). However, some studies clearly indicated vertical patterns of zooplankton in such systems (Kuczyńska-Kippen, 2001; Meerhoff et al., 2007).

Our knowledge of the vertical distribution of microcrustacean zooplankton in small (up to a few hectares) and shallow $(<2 \mathrm{~m})$ ponds and pools are even more limited 
compared to shallow lakes. Only a few studies dealt with such patterns. Among them, Ranta and Nuutinen (1985) documented diel vertical migrations of two Daphnia species in rock pools (20-150 cm max. depths) but could not satisfactory identify its drivers. Gilbert and Hampton (2001) observed differences in the vertical distribution of the cyclopoid copepod Tropocyclops extensus Kiefer between noon and midnight in a 150 -cm-deep pond, which was attributed to predation by notonectids. The vertical habitat choice of Daphnia longispina O. F. Müller in a $50-\mathrm{cm}$-deep arctic pond was determined by either UVR or Chaoborus predation on sunny and overcast days, respectively (Rautio et al., 2003). However, noticeable vertical variation in the physicochemical variables affecting the distribution of zooplankton was generally not reported from ponds and pools; an exception was described from an extreme habitat, a high-altitude (about $2500 \mathrm{~m}$ ) crater pond, where Blinn and Green (1986) found sharp gradients of temperature and DO at some occasions during a 3-year period.

Shallow waterbodies generally do not exhibit stratification for an extended time, but may stratify thermally for shorter periods, mainly on a diel basis (Ranta and Nuutinen, 1985; Branco and Torgersen, 2009). Other vertical gradients of physicochemical variables (e.g., nutrients, DO) may also develop following a diurnal cycle causing micro-scale (within $1 \mathrm{~m}$ ) heterogeneity of the water column, which can be highly important for both phyto- and zooplankton (Barker et al., 2010). Especially in productive lakes, the concentration of DO highly fluctuates during the day: the water column may be oversaturated during daytime, while critical oxygen depletion can occur at night (Brönmark and Hansson, 1998; Ford et al., 2002). The presence of sharp DO gradients may be more pronounced in ponds with small surface area, often inhabited by dense macrophyte stands, which moderate the effect of wind turbulence. Microcrustaceans living in ponds and pools are adapted to high fluctuations of DO concentration and even temporary anoxia (Fox, 1948; Herbert, 1954; Heisey and Porter, 1977). However, there is a lack of studies investigating the spatial distribution of microcrustaceans in small and extremely shallow habitats $(<1 \mathrm{~m})$, which may strongly depend on the concentration of DO.

In lowland peatlands and mires, the high stock of dead plant material represents an enormous substrate for microbial decomposition. Especially in stagnant water bodies, which are usually densely overgrown by macrophytes, oxygen is used up rapidly by microbial and animal respiration and diffusion cannot compensate this effect. Therefore, anoxic conditions occur in the sediment or even in the water column (Moss, 1988; Rydin and Jeglum, 2006). This may lead to the vertical stratification of oxygen even in a shallow water column, having a strong influence on the inhabiting species. Hence, peatland ponds seem to be highly appropriate for testing the effect of oxygen on the diurnal vertical distribution of zooplankton.

The aim of the present study was to investigate diel vertical microdistribution patterns of microcrustacean zooplankton in relation to environmental variables. During a previous 2-year monitoring period (2010-2011) of lowland peat ponds in the Öreg-turján peatland at Ócsa (Central Hungary), consistently low DO concentrations were found in the water columns and anoxic conditions were identified in the lower layers (Cs.F. Vad, unpublished data). Therefore, we hypothesised that DO has a major influence on the vertical distribution of zooplankton, which may also change diurnally.

\section{Material and methods}

\section{Study area}

The Öreg-turján peatland at Ócsa is a Ramsar site and a Natura 2000 area. We chose the deepest of the previously monitored ponds for the present study, which is situated in the central part of the wetland $\left(19^{\circ} 12.412^{\prime} \mathrm{E} 47^{\circ} 17.609^{\prime} \mathrm{N}\right)$ and originated from peat mining (abandoned in 1975). The water column is shallow $(<70 \mathrm{~cm})$ and the sediment layer is thick and muddy, mainly composed of dead plant materials (reed, sedges and tree leafs). The open area of the pond is $\sim 300 \mathrm{~m}^{2}$, which is surrounded by a dense reed belt. During summer, dense beds of bladderwort (Utricularia vulgaris L.), coontail (Ceratophyllum demersum L.) and duckweeds (Lemna spp.) appear along the edges of the open water. A detailed description of the microcrustacean community composition and seasonality was given by Vad et al. (2012). A recent fish faunistic survey (conducted on 21st August 2011) within the territory of the Öreg-turján resulted in only one fish species in our study pond, the European mudminnow (Umbra krameri Walbaum) (Keresztessy et al., 2012). This is a facultative air-breathing species, thus well-adapted to low oxygen conditions and typically inhabits dense macrophyte beds (Wanzenböck, 1995). Mudminnows were likewise only recorded from the submerged vegetation of our study pond during the fish survey (Katalin Keresztessy, unpublished data); therefore, in the open water, no considerable effect of fish on zooplankton can be expected.

\section{Sampling and data collection}

Sampling was performed during three 24-h periods in summer and early autumn 2011 (19-20th July, 17-18th August and 11-12th September). Weather conditions were always sunny with scarce clouds. Samples were taken four times (i.e., during different times of day) in each diel period: at sunrise (between 05:00 and 07:00), at mid-day (12:00 and 14:00), at sunset (18:00 and 20:00) and during night (01:00 and 03:00). In order to study the vertical distribution of zooplankton, samples were taken from three different depths $(0-20,20-40$ and $40-60 \mathrm{~cm}$ below the surface) with a transparent plastic Van Dorn bottle (height: $20 \mathrm{~cm}$, inner diameter: $6.2 \mathrm{~cm}$ ), which was used vertically. We also collected samples horizontally (from the unvegetated open water), both next to the submerged 
macrophyte zone and from the central part $(1.5 \mathrm{~m}$ away from the macrophytes) to investigate whether vertical patterns were similar between these two sites. All samples were taken in three replicates. Samples were preserved in $70 \%$ ethanol. All the individuals found in the samples were counted to determine the abundance of microcrustaceans. Cladocera species were identified according to the key from Gulyás and Forró (1999). As cyclopoid copepod species were rare, we used their summed densities in data analyses (but cyclopoid nauplii were managed separately).

At each occasion, $\mathrm{pH}$, water temperature, conductivity and DO were measured with a Eutech CyberScan PCD 650 field equipment (at 10,30 and $50 \mathrm{~cm}$, representing the middle of each layer, except for DO, that was recorded also at 5 and $20 \mathrm{~cm}$, to detect the rapid decline from the surface more precisely). Water for turbidity measures, as well as for chlorophyll- $a$ and phytoplankton samples were also collected in the same way as zooplankton, but without replicates. Turbidity was determined at the field with a Lovibond PC Checkit turbidity meter. The concentration of chlorophyll- $a$ was determined in the laboratory using the hot methanol extraction method (Wetzel and Likens, 1991). Phytoplankton samples were only taken at the three mid-day samplings, were fixed with Lugol's iodine solution and the abundance of species were determined according to Utermöhl (1958). The most frequent species were identified according to Tikkanen and Willén (1992) and Komárek and Anagnostidis (1998, 2005). Biovolume of the different taxa was calculated from individual measurements of cell sizes, using simple geometric equations and the parameters of 50 (most frequent species) or all individuals (rare taxa). Conversion from biovolume to carbon was estimated by applying a constant conversion factor of $14 \%$ of algal wet weight (Rocha and Duncan, 1985; Vadstein et al., 1988).

Because in situ measurements of photosyntetic active radiation (PAR) and UVR were not possible, water samples were collected on 24th August 2011 and measurements were carried out on the following day at noon. A PUV-2500 Radiometer (Biospherical Instruments) with a plastic bowl affixed above the sensor was used to measure downwelling irradiance at different wavelengths (400-700 nm for PAR; 395, 380 and $340 \mathrm{~nm}$ for UVR), from which the attenuation coefficients $\left(K_{\mathrm{d}}\right)$ were calculated. A detailed description of this procedure is given by V.-Balogh et al. (2009). The $1 \%$ penetration depth at different wavelengths was calculated using the form $Z_{1 \%}=\ln 100 / K_{\mathrm{d}}$.

\section{Statistical analyses}

Diel vertical distribution of microcrustaceans was analysed by repeated measures ANOVA (RM ANOVA). As remarkable diel differences occurred in the densities (Table 2), we used percentages (square-root-transformed data) of individuals per depth layer as the dependent variable, while depth was treated as the main factor and time of day as the repeated factor. Separate models were constructed for the three sampling periods and different sites (except for the central part in August that was excluded because of low animal densities). Distribution of the most frequent species, Daphnia curvirostris Eylmann and Ceriodaphnia reticulata (Jurine), was also analysed with RM ANOVA. No models were constructed for C. reticulata from the central part in July and September due to the limited number of individuals. In the case of the hyponeustic Scapholeberis rammneri Dumont and Pensaert, altering vertical distribution due to changing environmental conditions was not expected. Thus, we excluded this species from the analyses, although it was quite abundant in July. In the case of significant ANOVAs, Tukey's HSD post hoc tests were applied to test for significant differences among the different depths.

Redundancy analysis (RDA) was used to explore the main environmental factors determining microcrustacean vertical distribution. Three separate RDA models were performed for the July, August and September data, separately. Our explanatory variable set contained water temperature, concentration of DO and chlorophyll- $a, \mathrm{pH}$, conductivity, turbidity and density of Chaoborus larvae occurring in the zooplankton samples, while site (i.e., central part or next to the macrophytes) was used as a covariable. Density of different microcrustacean taxa (average of the three replicate samples per depth), as well as environmental data (apart from $\mathrm{pH}$ ) were cubic root transformed prior to analyses. S. rammneri was again excluded. Manual backward selection was used to retain significant variables $(P<0.05)$. We performed a split-plot permutation design (split-plot $=$ time of day) with $n=999$ Monte-Carlo permutations as our data included repeated observations in time. Variance partitioning was performed on the significant predictors of July (concentration of DO, temperature) and September data (concentration of DO and chlorophyll- $a$ ).

Given the high variation in diurnal densities, we tested for significant differences using RM ANOVAs (for July, August and September data separately). We tested for a significant effect of time of day (repeated factor) and site on cubic-root-transformed density data of the total microcrustaceans and the different taxa separately, while depth was used as a covariable to take into account the high vertical variation. Tukey's HSD post hoc tests were applied to identify significant differences among different times of day within each sampling periods.

All analyses were performed in R ( $\mathrm{R}$ Development Core Team, 2009). RDA models were constructed with the "vegan" package (Oksanen et al., 2012).

\section{Results}

\section{Vertical profiles of environmental variables}

All the measured environmental variables exhibited constant, marked vertical patterns during our study period. $\mathrm{DO}$, water temperature and $\mathrm{pH}$ all decreased, while 


\section{Next to the macrophytes Central part}

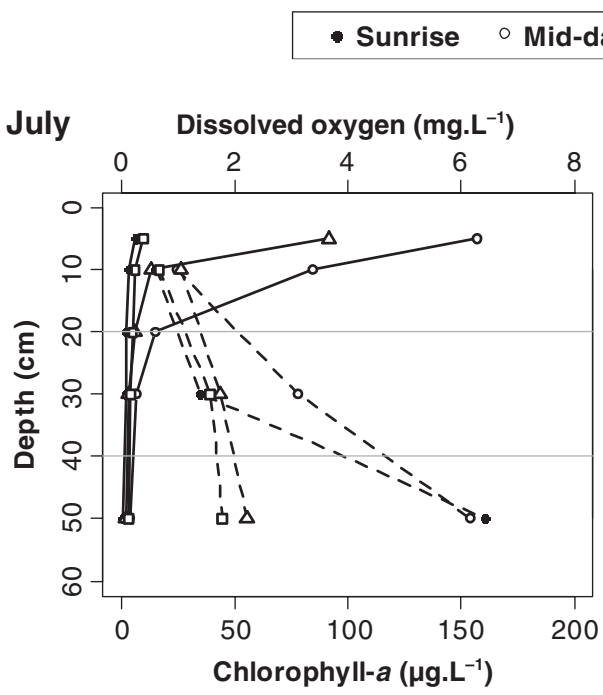

$\triangle$ Sunset $\square$ Night

Aug.

Dissolved oxygen (mg. $\left.\mathrm{L}^{-1}\right)$
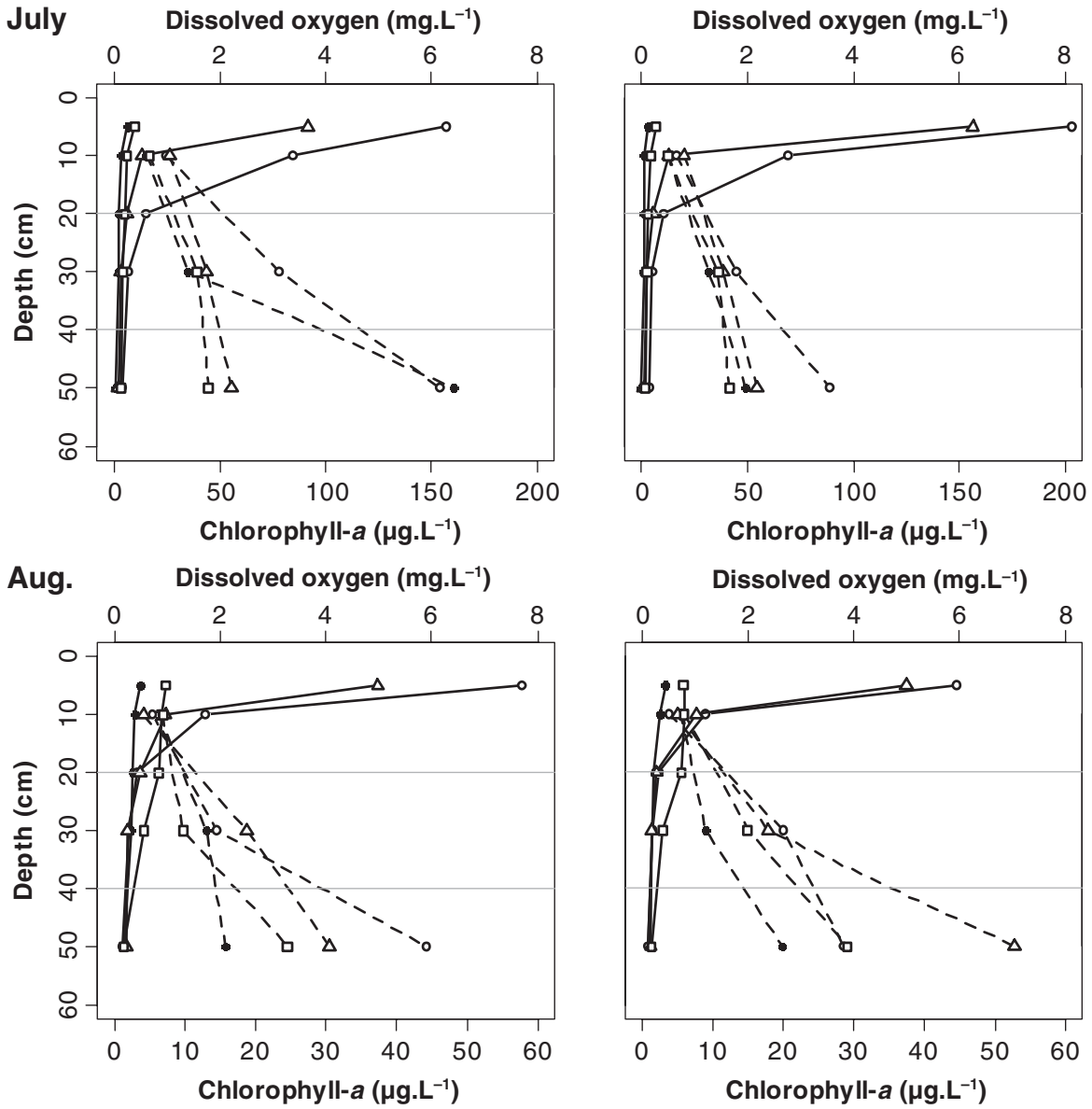

Sept.

Dissolved oxygen (mg.L-1)

Dissolved oxygen (mg.L-1)
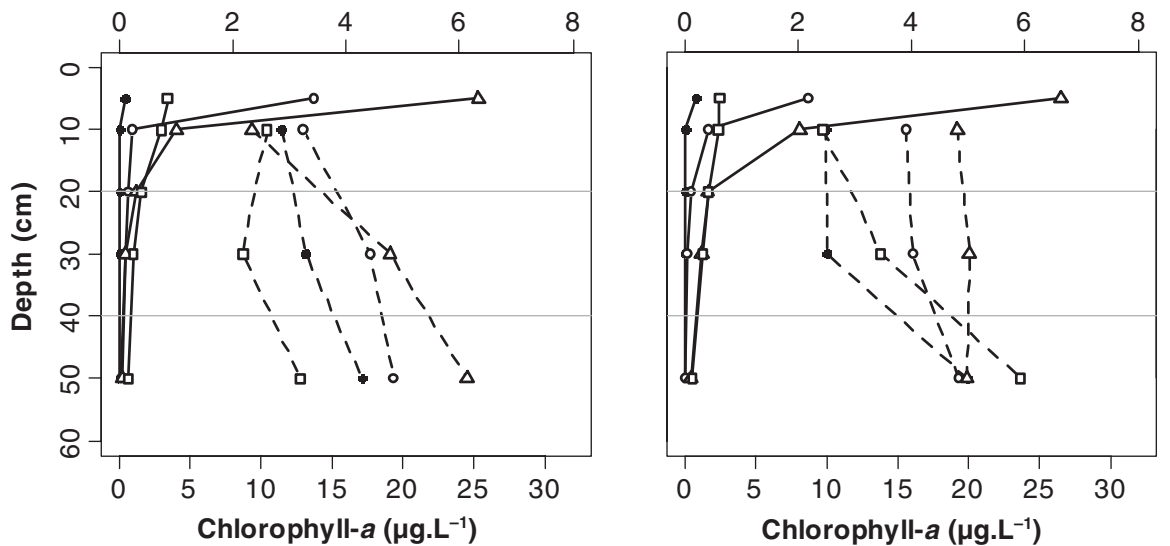

Fig. 1. Diel vertical patterns of DO (solid lines) and chlorophyll- $a$ (dashed lines) during the three 24-h periods. Horizontal grey lines separate the water layers from which the chlorophyll samples were taken.

chlorophyll- $a$, conductivity and turbidity increased with depth (Fig. 1 and Appendix Table A1 available online).

The concentration of DO was close to zero at sunrise and night and was highest during daytime (Fig. 1). However, the maximum saturation did not even reach $100 \%$ at $5 \mathrm{~cm}$ under the surface during the whole study period. At
$20 \mathrm{~cm}$ depth, DO never reached $1 \mathrm{mg} . \mathrm{L}^{-1}$ concentration, or $9 \%$ saturation throughout the study.

Chlorophyll- $a$ concentration increased with depth during all three sampling periods. In the most extreme case (morning of the July sampling), concentration in the bottom layer $(40-60 \mathrm{~cm})$ was more than ten times higher 
Table 1. Vertical distribution of phytoplankton biomass $\left(\mathrm{mg} \cdot \mathrm{L}^{-1}\right)$ next to the macrophytes during the three 24-h periods at mid-day. 0-20, 20-40 and 40-60 indicate the three different layers in $\mathrm{cm}$.

\begin{tabular}{|c|c|c|c|c|c|c|c|c|c|}
\hline & \multicolumn{3}{|c|}{ July } & \multicolumn{3}{|c|}{ August } & \multicolumn{3}{|c|}{ September } \\
\hline & $\overline{0-20}$ & $20-40$ & $40-60$ & $\overline{0-20}$ & $20-40$ & $40-60$ & $\overline{0-20}$ & $20-40$ & $40-60$ \\
\hline Cyanobacteria & 0.75 & 3.01 & 4.04 & 0.04 & 0.39 & 3.04 & 0.16 & 0.56 & 0.82 \\
\hline Chrysophyceae + Xanthophyceae & 0.00 & 0.00 & 1.83 & 0.00 & 0.06 & 1.83 & 0.00 & 0.00 & 0.01 \\
\hline Bacillariophyceae & 0.00 & 0.02 & 0.00 & 0.01 & 0.02 & 0.00 & 0.04 & 0.09 & 0.02 \\
\hline Cryptophyta & 0.01 & 0.69 & 0.44 & 0.00 & 0.00 & 0.44 & 0.19 & 0.55 & 0.23 \\
\hline Euglenophyta & 0.05 & 0.00 & 0.00 & 0.01 & 0.02 & 0.00 & 0.10 & 0.15 & 0.28 \\
\hline Chlorophyceae & 0.01 & 0.04 & 0.06 & 0.00 & 0.00 & 0.06 & 0.00 & 0.02 & 0.03 \\
\hline Wet weight & 0.83 & 3.76 & 6.38 & 0.06 & 0.49 & 5.37 & 0.50 & 1.37 & 1.40 \\
\hline Carbon biomass & 0.12 & 0.53 & 0.89 & 0.01 & 0.07 & 0.75 & 0.07 & 0.19 & 0.20 \\
\hline
\end{tabular}

Table 2. The diel densities of total microcrustaceans (ind. $\mathrm{L}^{-1}$ ) occurring in the different water layers during the three 24-h periods (data are the means of the three replicate samples $\pm \mathrm{SE} ; \mathrm{NM}=$ next to the macrophytes, $\mathrm{CP}=$ central part).

\begin{tabular}{|c|c|c|c|c|c|c|c|c|c|}
\hline \multirow{2}{*}{\multicolumn{2}{|c|}{ Depth $(\mathrm{cm})$}} & \multicolumn{2}{|c|}{ Sunrise } & \multicolumn{2}{|c|}{ Mid-day } & \multicolumn{2}{|c|}{ Sunset } & \multicolumn{2}{|c|}{ Night } \\
\hline & & NM & $\mathrm{CP}$ & $\overline{\mathrm{NM}}$ & $\mathrm{CP}$ & $\overline{\mathrm{NM}}$ & $\mathrm{CP}$ & NM & $\mathrm{CP}$ \\
\hline \multirow[t]{3}{*}{$\overline{\text { July }}$} & $0-20$ & $123.3 \pm 24.7$ & $42.0 \pm 11.4$ & $396.0 \pm 174.2$ & $234.7 \pm 142.0$ & $344.0 \pm 109.2$ & $903.3 \pm 83.5$ & $21.3 \pm 4.8$ & $10.7 \pm 1.3$ \\
\hline & $20-40$ & $9.3 \pm 5.3$ & $1.3 \pm 0.7$ & $28.0 \pm 3.5$ & $46.0 \pm 21.0$ & $42.0 \pm 8.3$ & $39.3 \pm 8.4$ & $0.7 \pm 0.7$ & $0.7 \pm 0.7$ \\
\hline & $40-60$ & $4.0 \pm 2.0$ & $0.0 \pm 0.0$ & $10.7 \pm 2.4$ & $6.0 \pm 0.7$ & $7.3 \pm 5.5$ & $1.3 \pm 1.3$ & $0.0 \pm 0.0$ & $0.0 \pm 0.0$ \\
\hline \multirow[t]{3}{*}{ Aug. } & $0-20$ & $172.7 \pm 62.7$ & $48.7 \pm 7.51$ & $416.7 \pm 42.3$ & $188.7 \pm 100.3$ & $326.7 \pm 59.0$ & $441.3 \pm 57.8$ & $169.3 \pm 97.1$ & $111.3 \pm 24.9$ \\
\hline & $20-40$ & $10.0 \pm 4.2$ & $9.3 \pm 1.8$ & $138.7 \pm 58.7$ & $92.0 \pm 51.6$ & $43.3 \pm 3.7$ & $32.7 \pm 8.4$ & $96.7 \pm 45.4$ & $94.0 \pm 45.0$ \\
\hline & $40-60$ & $5.4 \pm 3.5$ & $2.0 \pm 1.2$ & $38.7 \pm 11.2$ & $6.7 \pm 4.8$ & $5.3 \pm 3.5$ & $6.0 \pm 2.3$ & $4.7 \pm 0.7$ & $2.7 \pm 1.3$ \\
\hline \multirow[t]{3}{*}{ Sept. } & $0-20$ & $8.0 \pm 3.1$ & $0.0 \pm 0.0$ & $18.7 \pm 4.1$ & $16.0 \pm 4.2$ & $33.3 \pm 2.4$ & $14.7 \pm 2.7$ & $35.3 \pm 14.3$ & $13.3 \pm 4.7$ \\
\hline & $20-40$ & $2.0 \pm 1.3$ & $0.0 \pm 0.0$ & $6.7 \pm 2.4$ & $3.3 \pm 0.7$ & $5.3 \pm 2.9$ & $2.7 \pm 1.3$ & $8.7 \pm 0.7$ & $7.3 \pm 1.8$ \\
\hline & $40-60$ & $1.3 \pm 1.2$ & $0.0 \pm 0.0$ & $0.7 \pm 0.7$ & $0.0 \pm 0.0$ & $2.0 \pm 1.2$ & $2.0 \pm 1.2$ & $5.3 \pm 1.3$ & $0.7 \pm 0.7$ \\
\hline
\end{tabular}

than at the surface. Patterns were similar in the central part and next to the macrophytes (Fig. 1).

Similarly to chlorophyll- $a$, phytoplankton biomass also remarkably increased downwards (Table 1). Total biomass mainly consisted of cyanobacteria with the dominant species Cyanothece aeruginosa (Nägeli) Komárek and Planktothrix agardhii (Gomont) Anagnostidis and Komárek. In July and August, blue-greens almost exclusively dominated the surface layer, while in the middle and bottom layers, cryptophytes and chrysophytes reached considerable amount of biomass, with the dominant species Cryptomonas ovata Ehrenberg and Syncrypta sp. The vertical stratification was less apparent in September (Table 1).

The $1 \%$ penetration depth of visible light (photic depth) would be $2.2 \pm 0.3 \mathrm{~m}$, which means that the whole 60 -cm-deep water column is well-lighted. $1 \%$ depths for UVR at different wavelengths were $32.3 \pm 0.6(395 \mathrm{~nm})$, $26.3 \pm 1.3(380 \mathrm{~nm})$ and $15.5 \pm 1.0 \mathrm{~cm}(340 \mathrm{~nm})$. Considering that, UV-B radiation attenuated above these depths.

\section{Distribution of zooplankton}

During the first two sampling periods (in July and August), D. curvirostris was by far the most frequent taxon (34.6-67.4 and 40.1-72.9\% of all collected individuals per time of day), followed by $S$. rammneri in July (0-38.0\%) and $C$. reticulata in August (17.6-45.3\%). September samples were remarkably different, as D. curvirostris almost completely disappeared and the community was mainly composed of cyclopoid nauplii and $C$. reticulata. This also resulted in an overall decline of zooplankton density, e.g., the diel maxima in July and August were $903.3 \pm 122.5$ and $416.7 \pm 42.3$ ind. $\mathrm{L}^{-1}$ (experienced exclusively in the surface layers), while it was only $35.3 \pm 14.3$ ind. $\mathrm{L}^{-1}$ in September (Table 2).

Percentages of microcrustaceans were always highest in the upper $20 \mathrm{~cm}$ layer (both at the site next to the macrophytes and the central part), which was indicated by the significant "depth" factor in RM ANOVA and Tukey's HSD post hoc tests. Usually, hardly any animals were found in the lowest layer (Fig. 2, Table 3).

Time of day $\times$ depth interaction was not significant in July and September, suggesting no difference in the diel vertical distribution of zooplankters, however, the interaction of these factors proved to be significant in August (Table 3). At mid-day and night, percentages of microcrustaceans were considerably higher in the middle layer than at sunrise and sunset (Fig. 2). The interaction was also significant in the cases of the two dominant species $D$. curvirostris and $C$. reticulata, however, it was more apparent in the case of D. curvirostris (Fig. 3, Table 3).

Concentration of DO, water temperature and chlorophyll- $a$ concentration proved to be significant predictors of vertical distribution in at least one of the RDA models. Among them, only DO was significant in all three sampling periods; moreover, it was the only significant variable in August (Fig. 4). In July, DO alone explained 

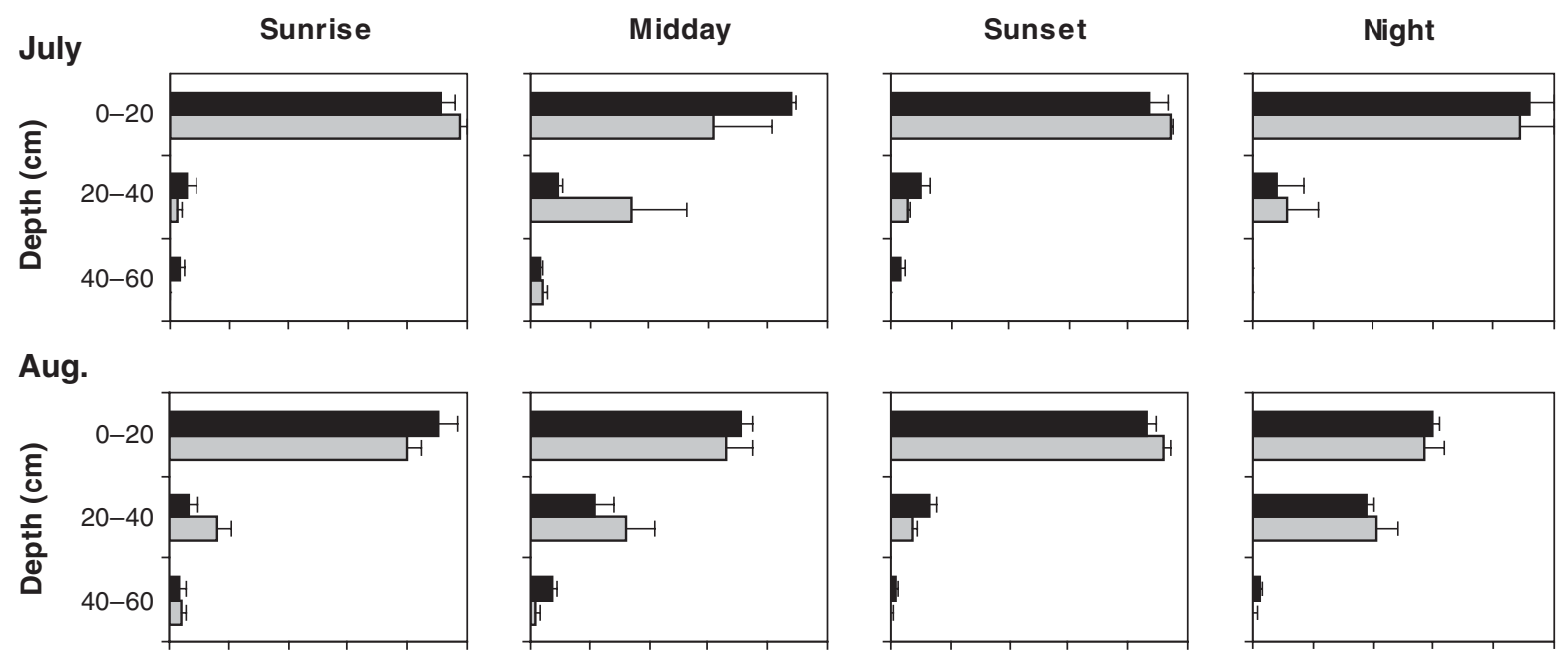

Sept.
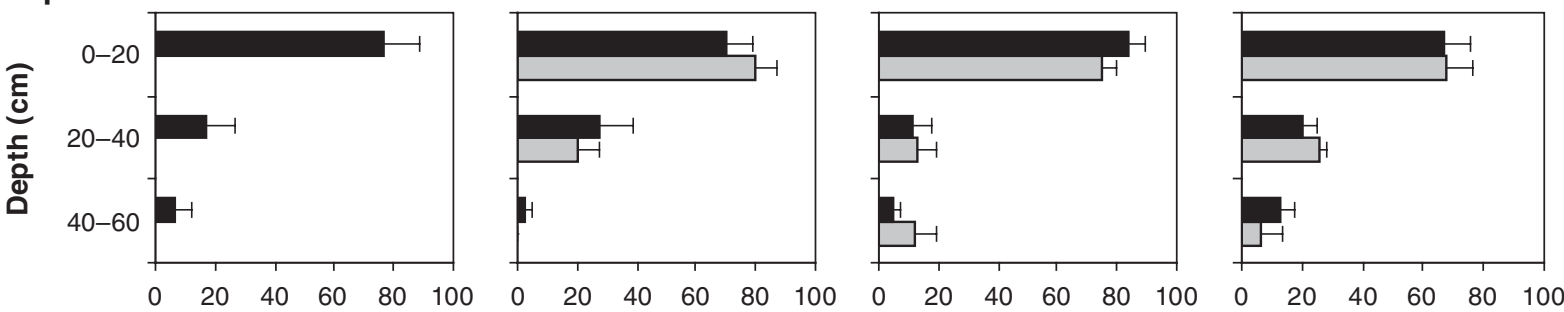

Percentage of individuals (\%)

Fig. 2. Diel vertical distribution of total microcrustaceans during the three 24-h periods. Data represent the percentages of microcrustaceans occurring in the different water layers (mean of the three replicate samples $+1 \mathrm{SE}$ ). Black bars refer to the sampling site next to the submerged macrophytes, while the grey ones refer to the ones in the central part of the pond.

Table 3. Results of the two-way RM ANOVA testing for the effects of depth and the interaction of depth and time of day on the diel vertical distribution of total microcrustaceans, as well as Daphnia curvirostris and Ceriodaphnia reticulata. Analyses were carried out separately for the three $24-\mathrm{h}$ periods and two sites $(\mathrm{NM}=$ next to the macrophytes, $\mathrm{CP}=$ central part). Abbrev. for depths: $\mathrm{S}=$ surface layer $(0-20 \mathrm{~cm}), \mathrm{M}=$ middle layer $(20-40 \mathrm{~cm}), \mathrm{B}=$ bottom layer $(40-60 \mathrm{~cm})$. Depths were ordered according to Tukey's HSD post hoc tests $(P<0.05)$. The $F$ values and the respective degrees of freedom (in parentheses) are given in all cases. Squareroot-transformed percentage data of microcrustaceans in each vertical layer were used in the analyses.

\begin{tabular}{|c|c|c|c|c|c|c|c|c|c|c|c|}
\hline \multirow{3}{*}{$\overline{\text { Total }}$} & \multirow{5}{*}{$\begin{array}{l}\text { July } \\
\text { Aug. } \\
\text { Sept. }\end{array}$} & \multicolumn{6}{|c|}{ Depth } & \multicolumn{4}{|c|}{ Time of day $x$ depth } \\
\hline & & \multicolumn{3}{|c|}{ NM } & \multicolumn{3}{|c|}{$\mathrm{CP}$} & \multicolumn{2}{|l|}{ NM } & \multicolumn{2}{|l|}{$\mathrm{CP}$} \\
\hline & & $\mathrm{S}>\mathrm{M}>\mathrm{B}$ & $233.70_{(2,6)}$ & $* * *$ & $\mathrm{~S}>\mathrm{M}=\mathrm{B}$ & $73.95_{(2,6)}$ & $* * *$ & $0.76_{(6,18)}$ & ns & $1.75_{(6,18)}$ & ns \\
\hline & & $\mathrm{S}>\mathrm{M}>\mathrm{B}$ & $223 \cdot 66_{(2,6)}$ & $* * *$ & $\mathrm{~S}>\mathrm{M}>\mathrm{B}$ & $124.25_{(2,6)}$ & $* * *$ & $8.50_{(6,18)}^{(10)}$ & $* * *$ & $8.62_{(6,18)}^{(0,10)}$ & \\
\hline & & $\mathrm{S}>\mathrm{M}=\mathrm{B}$ & $187 \cdot 67_{(2,6)}$ & $* * *$ & & & & $1.59_{(6,18)}$ & ns & & \\
\hline \multirow[t]{2}{*}{ Daphnia curvirostris } & July & $\mathrm{S}>\mathrm{M}=\mathrm{B}$ & $184.38_{(2,6)}$ & $* * *$ & $\mathrm{~S}>\mathrm{M}=\mathrm{B}$ & $60.87_{(2,6)}$ & $* * *$ & $0.65_{(6,18)}$ & ns & $1.86_{(6,18)}$ & $\mathrm{ns}$ \\
\hline & Aug. & $\mathrm{S}>\mathrm{M}>\mathrm{B}$ & $101.52_{(2,6)}$ & $* * *$ & $\mathrm{~S}>\mathrm{M}>\mathrm{B}$ & $47.66_{(2,6)}$ & $* * *$ & $15.45_{(6,18)}$ & $* * *$ & $10.55_{(6,18)}$ & \\
\hline \multirow[t]{3}{*}{ Ceriodaphnia reticulata } & July & $\mathrm{S}>\mathrm{M}=\mathrm{B}$ & $39.87_{(2,6)}$ & $* * *$ & & & & $1.40_{(6,18)}$ & ns & & \\
\hline & Aug. & $\mathrm{S}>\mathrm{M}>\mathrm{B}$ & $715.48_{(2,6)}$ & $* * *$ & $\mathrm{~S}>\mathrm{M}>\mathrm{B}$ & $107 \cdot 15_{(2,6)}$ & $* * *$ & $12 \cdot 11_{(6,18)}$ & $* * *$ & $3.32_{(6,18)}$ & * \\
\hline & Sept. & $\mathrm{S}>\mathrm{M}=\mathrm{B}$ & $364 \cdot 67_{(2,6)}$ & $* * *$ & & & & $2.09_{(6,18)}$ & ns & & \\
\hline
\end{tabular}

Significance levels: "ns" $P>0.1$, “.” $P<0.1$, “*” $P<0.05$, “**” $P<0.01$, “***” $P<0.001$.

only $3 \%$ of total variance in zooplankton densities, temperature had a pure variance of $12 \%$, while their shared effect was much higher (35\%). In September, DO had a higher importance (26\% pure variance) compared to chlorophyll- $a(2 \%)$ and their shared effect $(7 \%)$.

Significant diel changes were found in the case of total microcrustacean abundance (Table 4). Densities at sunrise were always significantly lower than during the day (midday and sunset). During the July sampling, we observed a striking and almost complete disappearance of zooplankters at night. Densities were usually significantly higher next to the macrophytes compared to the central part, which can be mainly attributed to $C$. reticulata and Cyclopoida (Table 4). 

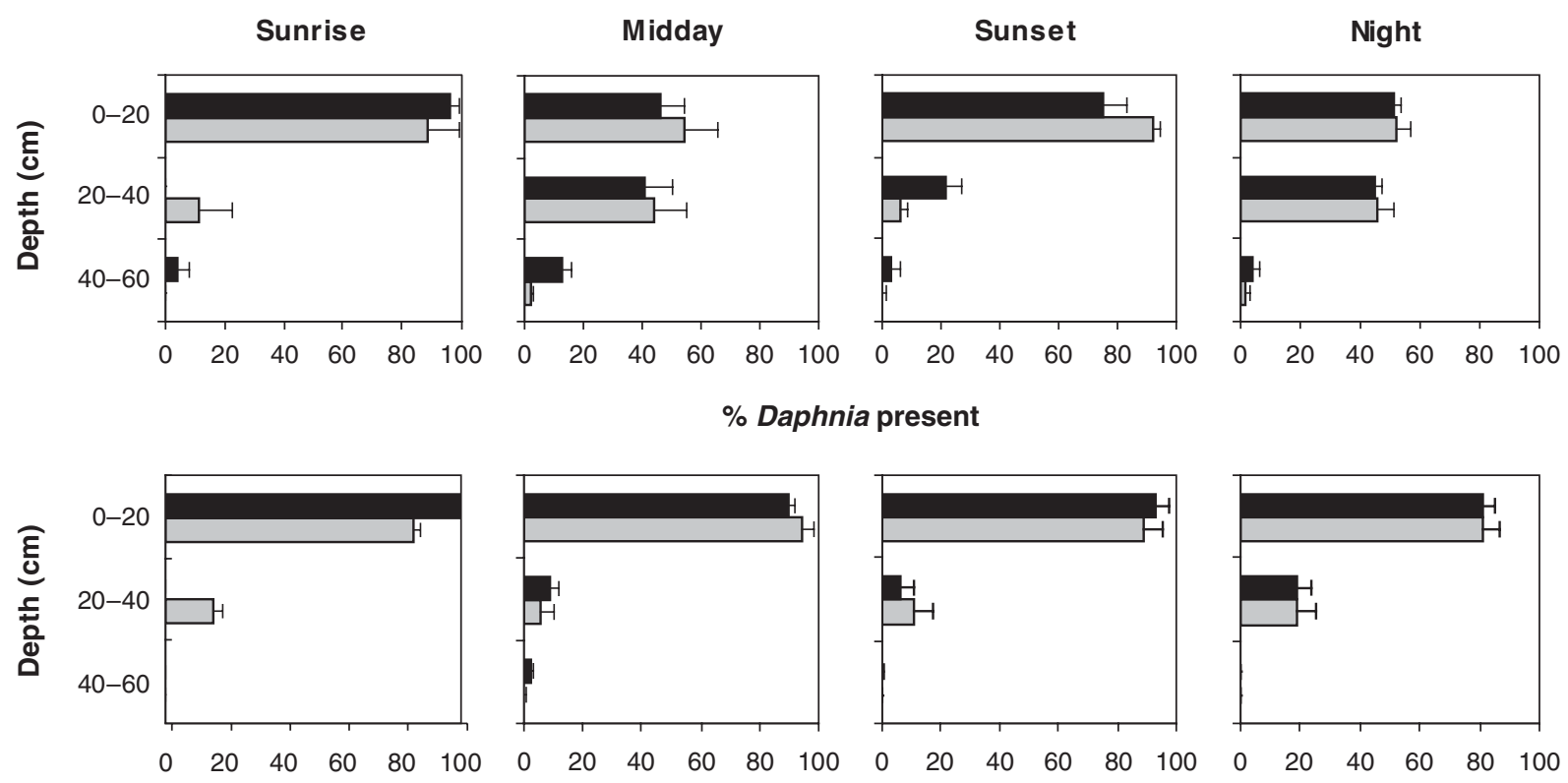

$\%$ Ceriodaphnia present

Fig. 3. Diel vertical distribution of Daphnia curvirostris and Ceriodaphnia reticulata in August, when significant differences in the diel distribution were found. Data represent the percentages of the two species occurring in the different water layers (mean of the three replicate samples $+1 \mathrm{SE}$ ). Shading is as in Figure 2.

\section{Discussion}

Strikingly clear vertical gradients were found in both the environmental variables and zooplankton distribution in this very shallow pond. These patterns were highly similar for the three distinct 24 -h periods covering the late summer season.

The vertical distribution of microcrustaceans was predominantly determined by the concentration of DO as indicated by the RDA models. It proved to be significant in all models; moreover, it was the only significant predictor in August and accounted for most of the explained variance in September. In July, water temperature explained a higher amount of variation than DO, but their shared fraction of explained variation was even higher, indicating covariance. Water temperature is an important factor influencing the distribution of microcrustaceans in thermally stratified lakes (Orcutt and Porter, 1983; Kessler and Lampert, 2004). However, it is unlikely to have a leading role in our case, as the whole water column of the pond was nearly isothermal during sunrise and night (and in August and September, even at mid-day; Appendix Table A1 available online), while the restricted distribution of zooplankton was constant.

Therefore, the observed distribution of microcrustaceans that was limited mainly to the upper 20-cm-layer was most likely due to severe hypoxia (low-oxygen conditions) or even anoxia in the lower layers. A similar phenomenon was found by Blinn and Green (1986) in a senescent, high altitude crater pond in Arizona, when the highest densities of zooplankton were seasonally most frequently restricted to the upper, well-oxygenated $30-\mathrm{cm}$ layer. The phenomenon that zooplanktons are restricted to the meta- and epilimnion is typical in thermally stratified larger lakes with hypoxia in the hypolimnion (Sell, 1998; Hembre and Megard, 2003). Under these conditions, even benthic species migrate upwards to the oxygenated layers (Tinson and Laybourn-Parry, 1985).

Hypoxia occurred even in the surface water during sunrise and night. DO concentrations below $3 \mathrm{mg} . \mathrm{L}^{-1}$ cause a rapid decline in the respiration and filtering rate of Daphnia (Heisey and Porter, 1977). However, limited oxygen availability stimulates the synthesis of haemoglobin, which results in bright red colour of the animals (Fox, 1948). We observed red colouration, indicating this response to low oxygen was occurring in our case. Cladocera species living in ponds or eutrophic systems are often likely to be exposed to oxygen limitation, thus have especially high regulatory ability on their haemoglobin levels (Kring and O'brien, 1976; Heisey and Porter, 1977). With increased haemoglobin content, Daphnia are able to survive at the DO level of $0.5 \mathrm{mg} . \mathrm{L}^{-1}$ (Weider and Lampert, 1985). Anoxic tolerance also seems to be welldeveloped, as e.g., Paul et al. (1998) found that Daphnia magna survived up to 1 day under complete lack of oxygen.

Chlorophyll- $a$ concentration and phytoplankton biomass exhibited an inverse vertical profile compared to zooplankton. We also found uneven vertical distribution of different phytoplankton taxa. In the surface layers, high frequency of cyanobacteria was present, while cryptomonads and chrysophytes reached considerable amount of biomass in the lower layers. We cannot be entirely sure about the driver of these phenomena, however, the numerous microcrustaceans (often hundreds of individuals, up to $903.3 \pm 122.5$ ind. $\mathrm{L}^{-1}$ of total zooplankton 

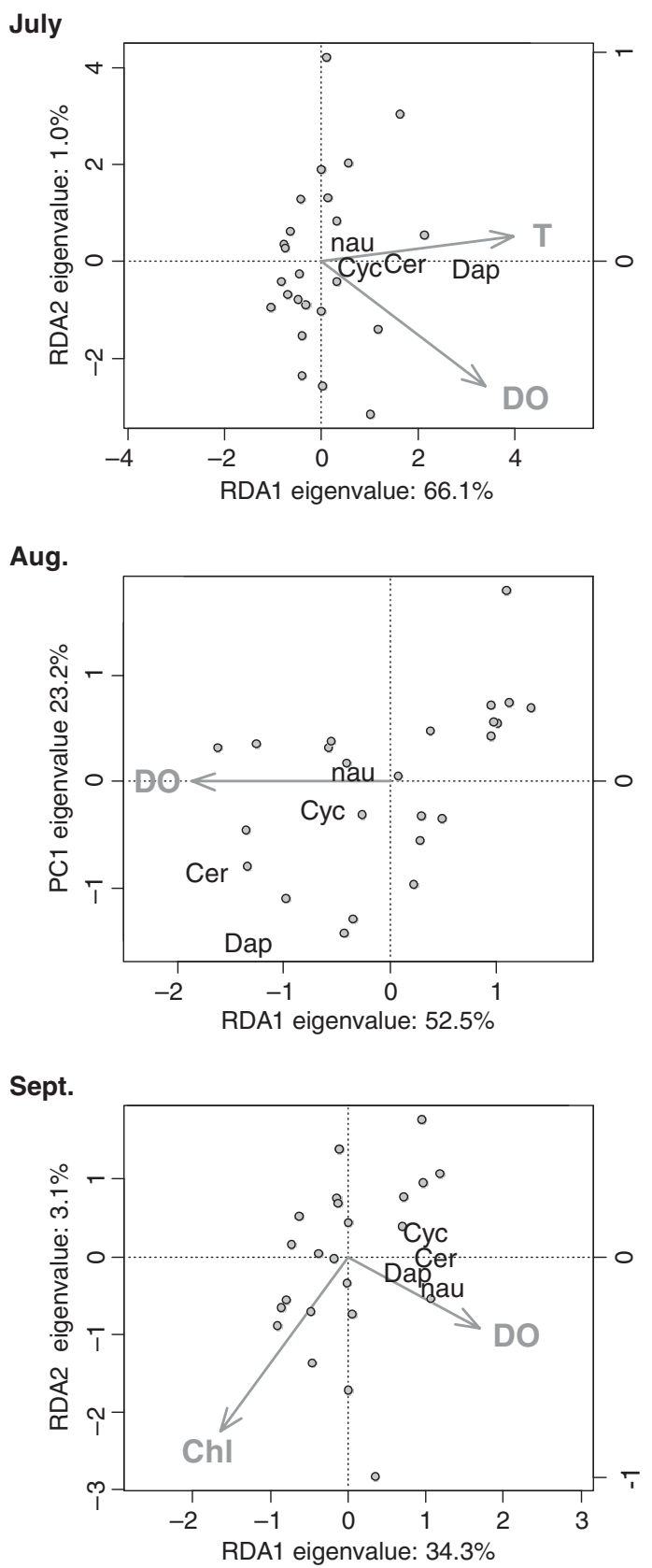

Fig. 4. RDA models constructed for the three 24-h periods, separately. Abbrev. for environmental variables (indicated by arrows): $\mathrm{DO}=$ concentration of dissolved oxygen, $\mathrm{T}=$ water temperature, $\mathrm{Chl}=$ chlorophyll- $a$. Abbrev. for species (indicated only by labels): Dap = Daphnia curvirostris, Cer = Ceriodaphnia reticulata, $\mathrm{Cyc}=$ cyclopoid copepods, nau = cyclopoid nauplii. Points indicate samples.

and $511.3 \pm 144.6$ ind. $\mathrm{L}^{-1}$ of large D. curvirostris) in the surface water can undisputedly have a high grazing pressure on the inhabiting phytoplankton. Grazing by Daphnia and other macrozooplankters has been previously identified as a major driver of the vertical distribution of phytoplankton by forcing some taxa to the oxic-anoxic boundary zone of lakes (Arvola et al., 1992; Massana et al., 1994), which frequently contributes to deep-water chlorophyll maxima (Pilati and Wurtsbaugh, 2003). Thus, the vertical profiles of plankton suggest a possible avoidance-response cascade induced by DO.

Food quality often has a higher importance for planktonic grazers than quantity (Gulati and DeMott, 1997). Cryptomonads are excellent food source for cladocerans (Ahlgren et al., 1990; Williamson et al., 1996), while cyanobacteria are known to be of low nutritional value (Ahlgren et al., 1990; Müller-Navarra et al., 2000; von Elert et al., 2003). Considering that, in our case, microcrustaceans faced with a pronounced trade-off on the vertical axis between higher quality food and better oxygen supply. Despite this, the highest ratio of individuals spent most of their time in the upper layer, which indicates a stronger role of oxygen limitation. We only found significant differences in the diel vertical distribution of zooplankters in August, most clearly exhibited by $D$. curvirostris, however, only to the middle layer. The carbon biomass of phytoplankton in the upper layer in August $\left(0.01 \mathrm{mg} . \mathrm{L}^{-1}\right)$ was well below a threshold food concentration of individual growth (around $0.05 \mathrm{mg}$ carbon. $\mathrm{L}^{-1}$ ) fairly consistently predicted for some Daphnia species (incl. Daphnia pulex, a very similar species to D. curvirostris; Andersen, 1997). Under these circumstances, expanding the lower limit of the distribution might be beneficial in spite of hypoxia. Haemoglobin-rich Daphnia are able to descend to the low-oxygen layer, thus utilizing its abundant food resources (Salonen and Lehtovaara, 1992; Sell, 1998). Migrating downwards, in our case, also reduces the likely interference of $D$. curvirostris with $C$. reticulata, which latter species was very abundant in August (when significant differences in the diel vertical distribution were found). These two genera largely overlap in their food spectra (Lynch, 1978) and small cladocerans like Ceriodaphnia are usually better competitors than larger Daphnia under low food supply (Romanovsky and Feniova, 1985).

The main role of UVR as a reason for the significant differences in the diel vertical distribution can be excluded, as in our pond, the $1 \%$ penetration depth for UV-A at $340 \mathrm{~nm}$ was $\sim 15 \mathrm{~cm}$. Thus, UV-B wavelengths, which are the most damaging for freshwater zooplankton (Rautio and Tartarotti, 2010) were likely absorbed in the upper few centimetres of the water column. Moreover, we did not find significant diel vertical migration during two of the three investigated 24-h periods (i.e., migrating downwards at mid-day to avoid harmful UVR), despite the highly similar weather conditions.

We can also omit the possible role of fish as a driver of the diurnal vertical aggregation of microcrustaceans. European mudminnows exclusively inhabit dense macrophyte beds (which preference was confirmed during the investigations of Keresztessy et al., 2012) and avoid open water due to their poor swimming ability. Therefore, in the unvegetated zone of the pond, the effect of fish on zooplankton can be neglected.

Although we did not sample the shoreline plant beds, the disappearance of zooplankters from the open water during the night until sunrise strongly suggests that they 
Table 4. Results of the two-way RM ANOVA testing for the effects of site and time of day on the diel densities of microcrustaceans. Analyses were carried out separately for the three 24-h periods. Abbrev. for sites: $\mathrm{NM}=$ next to the macrophytes, $\mathrm{CP}=\mathrm{central}$ part; abbrev. for time of day: $\mathrm{R}=$ sunrise, $\mathrm{M}=$ mid-day, $\mathrm{S}=$ sunset, $\mathrm{N}=$ night. Times of day were ordered according to Tukey's HSD post hoc tests $(P<0.05)$. The $F$ values and the respective degrees of freedom (in parentheses) are given in all cases. Density data of microcrustaceans were used in the analysis after cubic root transformation.

\begin{tabular}{|c|c|c|c|c|c|c|c|}
\hline \multirow{2}{*}{$\overline{\text { Total }}$} & \multirow[b]{2}{*}{ July } & \multicolumn{3}{|c|}{ Site } & \multicolumn{3}{|c|}{ Time of day } \\
\hline & & $\mathrm{NM}=\mathrm{CP}$ & $1.58_{(1,15)}$ & ns & $\mathrm{R}<\mathrm{M}=\mathrm{S}>\mathrm{N}$ & $40.17_{(3,45)}$ & $* * *$ \\
\hline & Aug. & $\mathrm{NM}>\mathrm{CP}$ & $5.46_{(1,15)}$ & $*$ & $\mathrm{R}<\mathrm{M}=\mathrm{S}=\mathrm{N}$ & $7.94_{(3,45)}$ & *** \\
\hline & Sept. & $\mathrm{NM}>\mathrm{CP}$ & $15.48_{(1,15)}$ & $* *$ & $\mathrm{R}<\mathrm{M}=\mathrm{S}=\mathrm{N}$ & $9.68_{(3,45)}$ & *** \\
\hline Daphnia curvirostris & July & $\mathrm{NM}=\mathrm{CP}$ & $0.46_{(1,15)}$ & ns & $\mathrm{R}<\mathrm{M}=\mathrm{S}>\mathrm{N}$ & $44.83_{(3,45)}$ & \\
\hline & Aug. & $\mathrm{NM}=\mathrm{CP}$ & $1.59_{(1,15)}$ & ns & $\mathrm{R}<\mathrm{M}=\mathrm{S}=\mathrm{N}$ & $8.94_{(3,45)}$ & \\
\hline Scapholeberis rammneri & July & $\mathrm{NM}=\mathrm{CP}$ & $0.53_{(1,15)}$ & ns & $\mathrm{R}<\mathrm{M}=\mathrm{S}$ & $10.63_{(3,30)}$ & \\
\hline & Aug. & $\mathrm{NM}=\mathrm{CP}$ & $0.73_{(1,15)}$ & ns & $\mathrm{R}<\mathrm{M}=\mathrm{S}>\mathrm{N}$ & $9.45_{(3,45)}$ & ** \\
\hline Ceriodaphnia reticulata & July & $\mathrm{NM}=\mathrm{CP}$ & $1.47_{(1,15)}$ & ns & $\mathrm{R}<\mathrm{M}=\mathrm{S}>\mathrm{N}$ & $9.32_{(3,45)}$ & \\
\hline & Aug. & $\mathrm{NM}>\mathrm{CP}$ & $7.72_{(1,15)}$ & $*$ & $\mathrm{R}<\mathrm{M}>\mathrm{S}=\mathrm{N}$ & $7.65_{(3,45)}$ & **** \\
\hline & Sept. & $\mathrm{NM}>\mathrm{CP}$ & $5.67_{(1,15)}$ & * & $\mathrm{R}=\mathrm{M}<\mathrm{S}>\mathrm{N}$ & $3.12_{(3,12)}$ & **** \\
\hline Cyclopoid copepods & July & $\mathrm{NM}>\mathrm{CP}$ & $13.18_{(1,15)}$ & ** & $\mathrm{R}=\mathrm{M}=\mathrm{S}=\mathrm{N}$ & $0.11_{(3,45)}$ & ns \\
\hline & Aug. & $\mathrm{NM}>\mathrm{CP}$ & $16.11_{(1,15)}$ & ** & $\mathrm{R}=\mathrm{M}=\mathrm{S}=\mathrm{N}$ & $1.61_{(3,45)}$ & ns \\
\hline Cyclopoid nauplii & Aug. & $\mathrm{NM}=\mathrm{CP}$ & $0.03_{(1,15)}$ & ns & $\mathrm{R}>\mathrm{M}=\mathrm{S}<\mathrm{N}$ & $18.11_{(3,45)}$ & **** \\
\hline & Sept. & $\mathrm{NM}>\mathrm{CP}$ & $11.01_{(1,15)}$ & $* *$ & $\mathrm{R}<\mathrm{M}=\mathrm{S}=\mathrm{N}$ & $13.90_{(3,45)}$ & \\
\hline
\end{tabular}

Significance levels: "ns" $P>0.1$, “.” $P<0.1$, “*” $P<0.05$, “**” $P<0.01$, “***” $P<0.001$.

are migrating into the macrophyte beds. Therefore, our results indicate reverse diel horizontal migration, i.e., migrating to the open water during daytime and congregating among the macrophytes during night. This pattern was previously observed by e.g., Nurminen and Horppila (2002), who explained it as an avoidance mechanism against young-of-the-year fish aggregating within the vegetation during the day. Lauridsen et al. (1998) found the same pattern in a fishless lake and explained it with predation by night-active pelagic invertebrates, e.g., Chaoborus. This is also possible in our case, as Chaoborus larvae were most abundant in our night samples, while only a few or no individuals occurred in the daytime samples (Appendix Fig. A1 available online). They were the most frequent in July, when the reverse diel horizontal migration pattern of zooplankton the most remarkable was (as indicated by the significantly lower densities at both sunrise and night compared to mid-day and sunset; Table 4), while fewer individuals of Chaoborus were found in August and only a single specimen in September (but still at night), when the pattern was less pronounced. Therefore, the altering diel density patterns may be a result of predator avoidance during the night (i.e., the tactile predator, Chaoborus), but we know much less about the adaptive role of daytime migration to the open water.

In summary, we found constant vertical microstratification of environmental factors and plankton in an extremely shallow water column. DO clearly had a predominant effect on the vertical distribution of zooplankton by maintaining its aggregation in the surface layers. Even in August, when we found vertical migration performed by D. curvirostris, likely because of food depletion in the surface layer, no or very few animals occurred in the bottom layer. Regarding the strong gradient of oxygen, the whole waterbody was similar to the metalimnetic oxycline of a thermally stratified lake. The vertical distributions of zooplankton and phytoplankton also support this similarity, as they correspond to lakes with metalimnetic algal maximum.

There is a growing interest in the ecology of ponds (Oertli et al., 2009; Boix et al. 2012) but plankton communities of peatland ponds are still poorly investigated. However, as these systems are generally oxygen-limited, the strong vertical stratification of plankton may be widespread in this habitat type and even in other ponds and pools with similarly high productivity. Therefore, investigations regarding micro-scale patterns could be an important part of monitoring such habitats and could significantly contribute to our knowledge on pond ecology.

Acknowledgements. The authors thank Csaba Decsov, Zsolt Vad, Csaba Éva and Ferenc Vad for their help during the field works, furthermore, Balázs Németh for conducting the radiation measurements and Boglárka Somogyi for related advice. We are also grateful to Robert Ptacnik for his valuable comments during the preparation of the manuscript, Bailey McMeans for kindly improving the English and the anonymous reviewers for their useful suggestions. The study was supported by the KTI-OTKA CNK 80140 project.

\section{References}

Ahlgren G., Lundstedt L., Brett M. and Forsberg C., 1990. Lipid composition and food quality of some freshwater phytoplankton for cladoceran zooplankters. J. Plankton Res., 12, 809-818.

Andersen T., 1997. Pelagic Nutrient Cycles: Herbivores as Sources and Sinks, Springer-Verlag, Berlin, 280 p. 
Arvola L., Salonen K., Kankaala P. and Lehtovaara A., 1992. Vertical distributions of bacteria and algae in a steeply stratified humic lake under high grazing pressure from Daphnia longispina. Hydrobiologia, 229, 253-269.

Barker T., Irfanullah H.MD. and Moss B., 2010. Micro-scale structure in the chemistry and biology of a shallow lake. Freshw. Biol., 55, 1145-1163.

Blinn D.W. and Green J., 1986. A pump sampler study of microdistribution in Walker Lake, Arizona, U.S.A.: a senescent crater lake. Freshw. Biol., 16, 175-185.

Boix D., Biggs J., Céréghino R., Hull A.P., Kalettka T. and Oertli B., 2012. Pond research and management in Europe: "Small is Beautiful". Hydrobiologia, 689, 1-9.

Branco B.F. and Torgersen T., 2009. Predicting the onset of thermal stratification in shallow inland waterbodies. Aquat. Sci., 71, 65-79.

Brönmark C. and Hansson L.-A., 1998. The Biology of Lakes and Ponds, Oxford University Press, New York, 216 p.

Burks R.L., Lodge D.M., Jeppesen E. and Lauridsen T.L., 2002. Diel horizontal migration of zooplankton: costs and benefits of inhabiting the littoral. Freshw. Biol., 47, 343-365.

Ford P.W., Boon P.I. and Lee K., 2002. Methane and oxygen dynamics in a shallow floodplain lake: the significance of periodic stratification. Hydrobiologia, 485, 97-110.

Fox H.M., 1948. The haemoglobin of Daphnia. Proc. R. Soc. Lond. Ser. B, Biol. Sci., 135, 195-212.

Gilbert J.J. and Hampton S.E., 2001. Diel vertical migrations of zooplankton in a shallow, fishless pond: a possible avoidance-response cascade induced by notonectids. Freshw. Biol., 46, 611-621.

Gliwicz Z.M., 1986. Predation and the evolution of vertical migration behavior in zooplankton. Nature, 320, 746-748.

Gulati R.D. and DeMott W.R., 1997. The role of food quality for zooplankton: remarks on the state-of-art, perspectives and priorities. Freshw. Biol., 38, 753-768.

Gulyás P. and Forró L., 1999. Az ágascsápú rákok (Cladocera) kishatározója [A guide for the identification of Cladocera occurring in Hungary - in Hungarian with English abstract], Vízi természet-és környezetvédelem 9, Környezetgazdálkodási Intézet, Budapest, 237 p.

Heisey D. and Porter K.G., 1977. The effect of ambient oxygen concentration on filtering and respiration rates of Daphnia galeata mendotae and Daphnia magna. Limnol. Oceanogr., 22, 839-845.

Hembre L.K. and Megard R.O., 2003. Seasonal and diel patchiness of a Daphnia population: An acoustic analysis. Limnol. Oceanogr., 48, 2221-2233.

Herbert M.R., 1954. The tolerance of oxygen deficiency in the water by certain Cladocera. Mem. Ist. Ital. Idrobiol., 8, 97-107.

Keresztessy K., May K., Weiperth A., Vad Cs.F. and Farkas J., 2012. Hosszú távú halfaunisztikai vizsgálatok és a veszélyeztetett lápi póc populációbiológiája a Duna-Tisza köze két Ramsari területén [Long-term fish faunistic research and the population biology of the threatened European mudminnow in two Ramsar wetlands of the Danube-Tisza Interfluve. - In Hungarian with English summary]. Pisces Hungarici, 6, 47-54.

Kessler K. and Lampert W., 2004. Depth distribution of Daphnia in response to a deep-water algal maximum: the effect of body size and temperature gradient. Freshw. Biol., 49, $392-401$.
Komárek J. and Anagnostidis K., 1998. Cyanoprokaryota 1. Teil: Chroococcales. In: Ettl H., Gärtner G., Heynig H. and Mollenhauer D. (eds.), Süsswasserflora von Mitteleuropa 19/1, Gustav Fischer Verlag, Stuttart, 548 p.

Komárek J. and Anagnostidis K., 2005. Cyanoprokaryota 2. Teil: Oscillatoriales. In: Büdel B., Krienitz L., Gärtner G. and Schagerl M. (eds.), Süsswasserflora von Mitteleuropa 19/2, Elsevier/Spektrum, Heidelberg, 759 p.

Kring R.L. and O'Brien W.J., 1976. Effect of varying oxygen concentrations on the filtering rate of Daphnia pulex. Ecology, 57, 808-814.

Kuczyńska-Kippen N., 2001. Diurnal vertical distribution of rotifers (Rotifera) in the Chara zone of Budzyńskie Lake, Poland. Hydrobiologia, 446/447, 195-201.

Lampert W., McCauley E. and Manly B.F.J., 2003. Trade-offs in the vertical distribution of zooplankton: ideal free distribution with costs? Proc. R. Soc. Lond. Ser. B, Biol. Sci., 270, 765-773.

Larsson P. and Lampert W., 2012. Finding the optimal vertical distribution: behavioural responses of Daphnia pulicaria to gradients of environmental factors and the presence of fish. Freshwat. Biol., 57, 2514-2525.

Lauridsen T.L. and Buenk I., 1996. Diel changes in the horizontal distribution of zooplankton in the littoral zone of two shallow eutrophic lakes. Arch. Hydrobiol., 137, 167-176.

Lauridsen T.L., Jeppesen E., Søndergaard M. and Lodge D., 1998. Horizontal migration of zooplankton: predatormediated use of macrophyte habitat. In: Jeppesen E., Søndergaard Ma., Søndergaard Mo. and Christoffersen K. (eds.), The Structuring Role of Submerged Macrophytes in Lakes, Springer-Verlag, New York, 233-239.

Lynch M., 1978. Complex interactions between natural coexploiters - Daphnia and Ceriodaphnia. Ecology, 59, 552-564.

Massana R., Gasol J.M., Jürgens K. and Pedrós-Alió C., 1994. Impact of Daphnia pulex on a metalimnetic microbial community. J. Plankton Res., 16, 1379-1399.

Meerhoff M., Iglesias C., Teixeira de Mello F., Clemente J.M., Jensen E., Lauridsen T.L., Jeppesen E., 2007. Effects of habitat complexity on community structure and predator avoidance behaviour of littoral zooplankton in temperate versus subtropical shallow lakes. Freshw. Biol., 52, 1009-1021.

Moss B., 1988. Ecology of Fresh Waters: Man and Medium, Blackwell Scientific Publications, London, 417 p.

Müller-Navarra D.C., Brett M.T., Liston A.M. and Goldman C.R., 2000. A highly unsaturated fatty acid predicts carbon transfer between primary producers and consumers. Nature, 403, 74-77.

Nurminen L.K.L. and Horppila J.A., 2002. A diurnal study on the distribution of filter feeding zooplankton: Effect of emergent macrophytes, $\mathrm{pH}$ and lake trophy. Aquat. Sci., 64, 198-206.

Oertli B., Céréghino R., Hull A. and Miracle R., 2009. Pond conservation: from science to practice. Hydrobiologia, $634,1-9$.

Oksanen J., Blanchet F.G., Kindt R., Legendre P., Minchin P.R., O’Hara R.B., Simpson G.L., Sólymos P., Stevens M.H.H., Wagner H., 2012. Vegan: Community ecology package, R package version 2.0-4, Available online at: http://CRAN.Rproject.org/package $=$ vegan .

Orcutt J.D. Jr. and Porter K.G., 1983. Diel vertical migration by zooplankton: constant and fluctuating temperature effects on 
life history parameters of Daphnia. Limnol. Oceanogr., 28, 720-730.

Paul R.J., Colmorgen M., Pirow R., Chen Y-H. and Tsai M-C., 1998. Systemic and metabolic responses in Daphnia magna to anoxia. Comp. Biochem. Physiol. A, Mol. Integr. Physiol., $120,119-125$.

Pilati A. and Wurtsbaugh W.A., 2003. Importance of zooplankton for the persistence of a deep chlorophyll layer: a limnocorral experiment. Limnol. Oceanogr., 48, 249-260.

Ranta E. and Nuutinen V., 1985. Daphnia exhibit diurnal vertical migration in shallow rock-pools. Hydrobiologia, 127, 253-256.

Rautio M. and Tartarotti B., 2010. UV radiation and freshwater zooplankton: damage, protection and recovery. Freshw. Rev., 3, 105-131.

Rautio M., Korhola A. and Zellmer I.D., 2003. Vertical distribution of Daphnia longispina in a shallow subarctic pond: does the interaction of ultraviolet radiation and Chaoborus predation explain the pattern? Polar Biol., 26, 659-665.

R Development Core Team, 2009. R: A language and environment for statistical computing, R Foundation for Statistical Computing, Vienna, Austria, ISBN 3-900051-07-0; Available online at: http://www.r-project.org.

Rhode S.C., Pawlowski M. and Tollrian R., 2001. The impact of ultraviolet radiation on the vertical distribution of zooplankton of the genus Daphnia. Nature, 412, 69-72.

Rocha O. and Duncan A., 1985. The relationship between cell carbon and cell volume in freshwater algal species used in zooplanktonic studies. J. Plankton Res., 7, 279-294.

Romanovsky Y.E. and Feniova I.Y., 1985. Competition among Cladocera: effect of different levels of food supply. Oikos, 44, 243-252.

Rydin H. and Jeglum J.K., 2006. The Biology of Peatlands, Oxford University Press, New York, 343 p.

Salonen K. and Lehtovaara A., 1992. Migrations of haemoglobin-rich Daphnia longispina in a small, steeply stratified, humic lake with an anoxic hypolimnion. Hydrobiologia, 229, 271-288.

Sell A.F., 1998. Adaptation to oxygen deficiency: Contrasting patterns of haemoglobin synthesis in two coexisting Daphnia species. Comp. Biochem. Physiol. A, Mol. Integr. Physiol., 120, 119-125.

Tikkanen T. and Willén T., 1992. Växtplanktonflora, Naturvårdsverket, Solna, $280 \mathrm{p}$.

Tinson S. and Laybourn-Parry J., 1985. The behavioural responses and tolerance of freshwater benthic cyclopoid copepods to hypoxia and anoxia. Hydrobiologia, 127, 257-263.

Utermöhl H., 1958. Zur Vervollkommung der qualitativen Phytoplankton-Methodik. Mitt. Int. Ver. Theor. Angew. Limnol., 9, 1-38.

Vad Cs.F., Horváth Zs., Kiss K.T., Ács É., Török J.K. and Forró L., 2012. Seasonal dynamics and composition of cladoceran and copepod assemblages in ponds of a Hungarian cutaway peatland. Int. Rev. Hydrobiol., 97, 420-434.

Vadstein O., Jensen A., Olsen Y. and Reinertsen H., 1988. Growth and phosphorus status of limnetic phytoplankton and bacteria. Limnol. Oceanogr., 33, 489-503.

V.-Balogh K., Németh B. and Vörös L., 2009. Specific attenuation coefficients of optically active substances and their contribution to the underwater ultraviolet and visible light climate in shallow lakes and ponds. Hydrobiologia, 632, 91-105.

von Elert E., Martin-Creuzburg D. and Le Coz J.R., 2003. Absence of sterols constrains carbon transfer between cyanobacteria and a freshwater herbivore (Daphnia galeata). Proc. R. Soc. Lond. Ser. B, Biol. Sci., 270, 1209-1214.

Wanzenböck J., 1995. Current knowledge on the European mudminnow, Umbra krameri Walbaum, 1792 (Pisces: Umbridae). Ann. Naturhist. Mus. Wien B, Bot. Zool., 97, 439-449.

Weider L.J. and Lampert W., 1985. Differential response of Daphnia genotypes to oxygen stress: respiration rates, hemoglobin content and low-oxygen tolerance. Oecologia, 65, 487-491.

Wetzel R.G. and Likens G.E., 1991. Limnological Analyses, Springer-Verlag, New York, 391 p.

Williamson C.E., Sanders R.W., Moeller R.E. and Stutzman P.L., 1996. Utilization of subsurface food resources for zooplankton reproduction: Implications for diel vertical migration theory. Limnol. Oceanogr., 41, 224-233.

Williamson C.E., Fischer J.M., Bollens S.M., Overholt E.P. and Breckenridge J.K., 2011. Towards a more comprehensive theory of zooplankton diel vertical migration: integrating ultraviolet radiation and water transparency into the biotic paradigm. Limnol. Oceanogr., 56, 1603-1623.

Winder M., Spaak P. and Mooij W.M., 2004. Trade-offs in Daphnia habitat selection. Ecology, 85, 2027-2036.

Zaret T.M. and Suffern J.S., 1976. Vertical migration in zooplankton as a predator avoidance mechanism. Limnol. Oceanogr., 21, 804-813. 